\title{
PERSEPSI DAN SIKAP MASYARAKAT TERHADAP RENCANA DIKEMBANGKANNYA WISATA SYARIAH (HALAL TOURISM) DI PROVINSI NUSA TENGGARA BARAT
}

\author{
${ }^{\mathbf{1}}$ Lalu Adi Permadi, ${ }^{2}$ Sri Darwini, ${ }^{\mathbf{3}}$ Weni Retnowati, ${ }^{4}$ Iwan Kusuma Negara, ${ }^{5}$ Emilia Septiani \\ 1,2,3,4,5 Fakultas Ekonomi dan Bisnis Universitas Mataram Jl. Majapahit 62 Mataram \\ adipermadi@unram.ac.id
}

\begin{abstract}
Abstrak : Tujuan penelitian ini adalah untuk mengetahui Persepsi dan Sikap Masyarakat Terhadap Rencana Dikembangkannya Wisata Syariah (Halal Tourism) Di Provinsi Nusa Tenggara Barat. Metode pembuktian terhadap tujuan penelitian tersebut menggunakan metode penelitian diskriptif. Hasil Penelitian ini menunjukkan bahwa Masyarakat Nusa Tenggara Barat memiliki persepsi yang BAIK terhadap rencana penerapan wisata halal di daerah ini, sikap yang POSITIF terhadap rencana penerapan wisata halal di daerah ini dan dari diagram Kartesius diketahui bahwa hasil rencana penerapan wisata halal dipersepsikan dan disikapi sangat tinggi oleh Masyarakat NTB. Saran untuk pengambil keputusan dalam hal ini Pemerintah NTB harus membuat kebijakan yang mempertahankan persepsi dan sikap itu tetap BAIK dan POSITIF. Dengan membuat kebijakan yang konkrit terkait dengan implementasi pariwisata halal, sehingga tidak sekedar pada tataran hukum atau peraturan daerah. Selain itu sosialisasi perlu dipercepat sehingga masyarakat paham bagaimana wisata halal tersebut akan diterapkan.
\end{abstract}

Kata kunci : wisata, syariah, persepsi, sikap, masyarakat

Abstract: The purpose of this study was to determine the local society's perceptions and attitudes toward the plan of developing Islamic Tourism (Halal Tourism) in the Province of West Nusa Tenggara. Method of proofing the objectives of the research was descriptive research. The results of this study indicated that the West Nusa Tenggara society has a good perception of the implementation of halal tourism in this area, a POSITIVE attitude to the implementation of halal tourism in this area and from the Cartesian diagram it is known that the results of the implementation plan of halal tourism is perceived and addressed very high by People of West Nusa Tenggara. West Nusa Tenggara Government should create policies that maintain perceptions and attitudes that remain GOOD and POSITIVE. By making concrete policy related to the implementation of halal tourism, so it's not just at the level of local laws or regulations. In addition, socialization needs to be accelerated so that people understand how the halal tourism will be applied.

Keywords: tourism, sharia, perception, attitude, society

\section{PENDAHULUAN}

Bagian penting dari ekonomi global saat ini adalah Ekonomi Islam. Pertumbuhan ekonomi Islam didukung oleh pertumbuhan jumlah penduduk Muslim Dunia yang berusia muda, pertumbuhan ekonomi pesat di Negara- negara Islam, nilai Islam yang mendorong bisnis dan gaya hidup Islami. Selain itu majunya hubungan ekonomi Negara-negara Islam yang tergabung dalam Organisasi Konferensi Islam, investasi perusahaan multinasional dan teknologi digital yang

Received: 2017-12-12| Reviced 2018-01-30| Accepted: 2018-01-31

Indexed : DOAJ, Garuda, Crossref, Google Scholar | DOI : https://doi.org/10.29313/amwaluna.v2i1.3275 
mempermudah hubungan antar Negara juga ikut mendorong kemajuan ekonomi Islam (Kemenpar, 2015).

Saat ini konsep syariah telah
memasuki bagian penting dari pertumbuhannya. Hal ini terlihat dengan terlihatnya konsep syariah di berbagai sisi kehidupan mulai dari produk makanan dan minuman, keuangan, hingga gaya hidup. Sebagai tren baru gaya hidup, maka banyak negara yang mulai memperkenalkan produk wisatanya dengan konsep halal dan Islami. Bahkan negara seperti Jepang, Australia, Thailand, Selandia Baru, dan sebagainya yang notabene bukan negara mayoritas berpenduduk muslim turut membuat produk wisata syariah (Kemenpar, 2015).

Perkembangan konsep wisata syariah berawal dari adanya jenis wisata jiarah dan religi (pilgrims tourism/spiritual tourism). Dimana pada tahun 1967 telah dilaksanakan konferensi di Cordoba, Spanyol oleh World Tourism Organization (UNWTO) dengan judul "Tourism and Religions: Contribution to the Dialogue of Cultures, Religions and Civilizations" (UNWTO, 2011 dalam Kemenpar, 2015). Wisata jiarah meliputi aktivitas wisata yang didasarkan atas motivasi nilai religi tertentu seperti Hindu, Budha, Kristen, Islam, dan religi lainnya. Seiring waktu, fenomena wisata tersebut tidak hanya terbatas pada jenis wisata jiarah/religi tertentu, namun berkembang ke dalam bentuk baru nilai- nilai yang bersifat universal seperti kearifan lokal, memberi manfaat bagi masyarakat, dan unsur pembelajaran. Dengan demikian bukanlah hal yang mustahil jika wisatawan muslim menjadi segmen baru yang sedang berkembang di arena pariwisata dunia (Kemenpar, 2015).

Dilihat dari faktor demografi, potensi wisatawan muslim dinilai cukup besar karena secara global jumlah penduduk muslim dunia sangat besar seperti Indonesia, Malaysia, Brunei Darussalam, Turki, dan negara- negara Timur Tengah dengan tipikal konsumen berusia muda/usia produktif, berpendidikan, dan memiliki disposable income yang besar. Menurut Pew Research Center (kelompok jajak pendapat di Amerika Serikat), bahwa jumlah penduduk muslim pada tahun 2010 sebesar 1,6 miliar atau 23 persen jumlah penduduk dunia. Jumlah penduduk muslim tersebut merupakan urutan kedua setelah umat Kristiani sebesar 2,2 miliar atau 31 persen penduduk dunia (Worldaffairsjournal, 2015). Dan diperkirakan hingga tahun 2050, penduduk muslim mencapai 2,8 miliar atau 30 persen penduduk dunia (Kemenpar, 2015). 
Untuk menangkap peluang kunjungan wisatawan dari kawasan Timur Tengah dan kawasan-kawasan lain yang berpenduduk mayoritas muslim, Nusa Tenggara Barat mulai mempersiapkan diri untuk mengimplementasikan pariwisata syariah atau yang disebut juga dengan pariwisata halal. Rencana ini diharapkan akan dapat meningkatkan jumlah kunjungan wisata Pulau Lombok (NTB) khususnya dan Indonesia umumnya. Selain itu, diharapkan akan dapat memicu pertumbuhan dan pengembangan ekonomi masyarakat dan wilayah yang memiliki daya ungkit yang kuat dalam mengentaskan masyarakat miskin menjadi masyarakat yang makmur secara sosial ekonomi. Masyarakat mendapat kesempatan yang luas untuk ikut mengembangkan pariwisata secara professional dalam bentuk usaha ekonomi pariwisata kreatif (transportasi, penginapan, restoran, cinderamata, kesenian, peramuwisata, porter, dan lain-lain) yang secara langsung dapat menunjang pengembangan geopark berkelanjutan (www.disbudpar.ntbprov.go. id, 2015).

Gubernur Nusa Tenggara Barat, Dr.TGH. M. Zainul Majdi sangat mendukung terlaksananya pariwisata halal di NTB. Dalam sambutannya pada sebuah seminar di Hotel Lombok Raya Juni 2015, Gubernur mengajak seluruk komponen dan pemangku kepentingan seperti unsur pemerintah, akademisi, tokoh agama, tokoh masyarakat, pelaku periwisata, pemerhati dan pegiat kepariwisataan serta stakeholders lainnya untuk secara bersama-sama mengembangkan pariwisata syariah (Halal Tourism) di Nusa Tenggara Barat. "Penduduk kita Nusa Tenggara Barat mayoritas Islam, masak kalah dengan daerah lain yang penduduknya tidak mayoritas Islam, papar Gubernur" (www.disbudpar.ntbprov.go.id, 2015).

Namun menurut Rusdan dkk (2014) selama ini, sebagian besar masyarakat Nusa Tenggara Barat lebih banyak bertindak sebagai "penonton" dari gebyar kehidupan industri pariwisata Nusa Tenggara Barat. Baru segelintir orang yang benar-benar dapat merasakan nikmatnya "kue wisata" tersebut. Pelibatan masyarakat secara besar-besaran biasanya hanya dilakukan pada saat seremoni peresmian suatu program atau unit bisnis pariwisata tertentu dengan tujuan agar memperoleh publisitas sebagai program yang melibatkan masyarakat. Masyarakat seringkali hanya mengetahui keberadaan program tersebut (karena telah disosialisaikan), namun tidak mengetahui sampai sejauh mana suatu program sudah dijalankan, karena tidak terlibat dalam implementasi program. Hal ini dapat dibuktikan dengan gagalnya Gunung Rinjani sebagai calon Geopark Dunia dibawah penilaian Lembaga 
Geopark Global Network-UNESCO, karena kelemahan pada beberapa faktor yang berkaitan dengan dukungan masyarakat dan pemerintah daerah.

Selain itu, banyak unit bisnis yang telah berkembang dalam industri pariwisata Nusa Tenggara Barat (seperti: Trek Management, Trek Organizer, Hotel, Restaurant, Guide, Porter, cinderamata, kelompok kesenian, dan lain-lain) dan masyarakat masyarakat yang umumnya berada dalam keterbatasan ekonomi dan wawasan tersebut tetap diperlakukan sebagai penonton. Andaipun mereka terlibat secara langsung, maka keterlibatan mereka hanya pada bagian atau bidang yang hanya dipandang dengan sebelah mata dan memperoleh tetesan nilai ekonomi yang sangat rendah. Idealnya, masyarakat diberikan kesempatan untuk dapat merasakan perkembangan pariwisata Nusa Tenggara Barat oleh pihak-pihak yang mengambil porsi besar tersebut baik langsung maupun tidak langsung (Rusdan dkk, 2014).

Seperti yang diberitakan oleh http://gayahidup.republika.co.id/ 29 Maret 2016 Pemerintah Provinsi Nusa Tenggara Barat (NTB) tengah mempersiapkan pantai ramah wisatawan perempuan. Ini merupakan bagian tambahan layanan opsional yang bisa diambil destinasi yang mengembangkan pariwisata halal. Kepala Badan Promosi Pariwisata Daerah (BPPD) NTB Taufan Rahmadi mengatakan, pemerintah sudah menegaskan quick wins Mandalika di sisi atraksi dengan mendukung kegiatan tematik berunsur keislaman. Rencananya akan dibuat masjid terbesar dan berunsur budaya NTB di sana. Ke dua, penyelesaian persoalan lahan yang sedang berlangsung proses hukumnya. Akan ada pula zona halal di Mandalika sebagai bagian masterplan PT Indonesia Tourism Development Corporation (ITDC) yang salah satunya pantai ramah Muslimah.

Pantai ramah Muslimah ini rencananya akan memanfaatkan salah satu area di Pantai yang masih masuk kawasan milik Pemerintah Provinsi NTB. Kawasan ini juga masih masuk dalam KEK Mandalika. Pantai ramah Muslim, lanjut Taufan, adalah layanan tambahan wisata pantai khususnya bagi kaum hawa yang ingin nyaman dan terlindung auratnya saat berkegiatan di pantai. Taufan menganalogikan pantai ini seperti kolam renang untuk anak-anak dan kolam untuk orang dewasa atau gerbong kereta khusus untuk perempuan. "Ini sematasemata pilihan memberi kenyaman kaum hawa bagi yang memang membutuhkan, bukan paksaan. Dari pembagian porsi kawasan pun tidak memblokir seluruh pantai, hanya area tertentu yang memang sudah ditentukan," ungkap Taufan 
Rencana program pantai ramah muslimah tersebut menimbulkan pro kontra di masyarakat. Media sosial seperti Facebook dan twitter banyak menampung keluhan mereka yang tidak suka atau pun suka terhadap progam pemerintah tersebut. Salah satunya adalah keluhan masyarakat tentang rencana ada pantai khusus perempuan atau pantai halal, dimana pantai halal atau pantai khusus muslimah akan menghilangkan privasi masyarakat untuk menggunakan pantai. Ini mengingat asset umum sepeti pantai akan dijadikan sebagai asset bisnis yang terbatas.

Kehadiran suatu industri (bisnis) atau penerapan program pemberdayaan (oleh pemerintah atau non-pemerintah) di suatu kawasan bersama teknologi dengan muatanmuatan ekonominya, akan memberikan dampak sosial berupa perubahan-perubahan dalam proses kehidupan sosial dan ekonomi pada masyarakat yang berada di industri atau program tersebut. Kehadirannya dapat menjadi ancaman potensial timbulnya kesenjangan sosial ekonomi jika tidak disertai dengan upaya memberikan pemahaman dan pelibatan kepada masyarakatnya. Oleh karena itulah, kehadiran bisnis dan teknologi moderen yang cenderung eksploratif harus diimbangi dengan pengembangan nilai-nilai dan sosial ekonomi masyarakat (Koentjaraningrat dan Budhisantoso, 1997 dalam Rusdan dkk, 2014).
Berdasarkan kenyataan tersebut, sebelum suatu bisnis moderen diluncurkan pada suatu kawasan diperlukan upaya penyiapan masyarakat terlebih dahulu agar mereka memiliki pengetahuan, wawasan, persepsi, dan sikap yang positif terhadap rencana pemerintah tersebut. Hal ini juga berlaku dalam kaitannya dengan upaya pemerintah yang ingin menerapkan wisata syariah di Nusa Tenggara Barat. Masyarakat yang berada dalam di NTB harus didekati dan diberikan pemahaman dengan pendekatan yang tepat, sesuai dengan karakteristik mereka, sehingga mau memberikan dukungan dan ikut terlibat secara aktif dalam perjalanan program tersebut. Untuk itu pemerintah dan pelaksana program atau pelaku usaha dituntut untuk mengetahui persepsi dan sikap masyarakat dalam di Kota Mataram dan sekitarnya terlebih dahulu.

Jauh sebelum Nusa Tenggara Barat berkembang sebagai suatu obyek wisata, menurut Rusdan dkk (2014) pada kasus Geopark Rinjani misalnya persepsi dan sikap masyarakat NTB terhadap pariwisata terbilang biasa-biasa saja (netral), dalam arti tidak menolak (negatif) maupun mendukung (positif). Masyarakat umumnya bersifat apatis (tidak peduli), bahkan ada sebagian yang memiliki kecenderungan untuk menolak, karena menganggap keberadaan pariwisata di wilayah mereka akan merusak hutan, alam, dan 
kehidupan sosial. Anggapan sebagian orang inilah yang cenderung menyebabkan masyarakat dalam NTB belum sepenuhnya memberikan dukungan terhadap program pariwisata tersebut. Namun dengan berjalannya waktu dan melihat jumlah kunjungan wisatawan ke Nusa Tenggara Barat yang semakin hari kian banyak dengan segala dampaknya (positif maupun negatif) tentu saja akan mengubah persepsi dan sikap masyarakat di NTB tersebut terhadap implementasi wisata syariah di Nusa Tenggara Barat.

Berdasarkan kenyataan tersebut diperlukan adanya kajian menyangkut persepsi dan sikap masyarakat di NTB terhadap implementasi wisata syariah di Nusa Tenggara Barat guna mempermudah pendekatan kepada masyarakat dalam menyongsong implementasi wisata syariah di Nusa Tenggara Barat.

Berdasarkan latar belakang tersebut permasalahannya dapat dirumuskan sebagai berikut :

i. Persepsi dan sikap masyarakat di NTB cenderung apatis terhadap implementasi wisata syariah di Nusa Tenggara Barat;

ii. Strategi dalam mengatasi sikap apatis masyarakat NTB terhadap program implementasi wisata syariah di Nusa Tenggara Barat. a. Memahami persepsi dan sikap masyarakat di NTB terhadap implementasi wisata syariah di Nusa Tenggara Barat;

b. Memahami faktor-faktor yang menyebabkan persepsi dan sikap masyarakat di NTB cendrung apatis terhadap implementasi wisata syariah di Nusa Tenggara Barat; dan

c. Menentukan strategi atau pendekatan yang cocok digunakan oleh pelaku usaha dan pemerintah dalam upaya memperoleh dukungan dan keterlibatan masyarakat demi keberhasilan dalam implementasi implementasi wisata syariah di Nusa Tenggara Barat.

Hasil penelitian akan memberikan manfaat yang sangat besar bagi banyak pihak antara lain, yakni :

a. membantu pihak-pihak yang memiliki kepedulian (pemerintah, pelaksana program, pelaku usaha kepariwisataan, LSM, dan stakeholders lainnya) dalam pengembangan masyarakat, lingkungan, dan kepariwisataan di Kota Mataram dan sekitarnya dalam mendekati, membangun kesiapan, dan memperoleh dukungan masyarakat;

b. sebagai ajang penyebaran dan pengembangan ilmu pengetahuan dalam masyarakat akademik dan masyarakat umum;

Penelitian ini bertujuan untuk : 
c. sebagai dasar bagi penelitian lanjutan yang lebih komprehensif.

\section{KAJIAN TEORI}

\section{Persepsi dan Sikap}

Persepsi merupakan suatu proses
dengan mana individu-individu
mengorganisasikan dan menafsirkan kesan
indera mereka agar memberi makna kepada
lingkungan mereka (Robbin, 2003 dalam
Rusdan dkk, 2014). Pada hakekatnya persepsi
adalah proses kognitif yang dialami seseorang
dalam menafsirkan dan memahami informasi
tentang lingkungannya melalui panca indera
(penglihatan, pendengaran, penciuman,
perasaan dan penghayatan).

Persepsi merupakan suatu proses kegiatan memilih, menerima dan mengatur dan menginterpretasikan informasi yang ada untuk mendapat gambaran yang berarti terhadap obyek tertentu (Kusmaningrum dan Dian, 2009). Persepsi adalah proses dimana individu memilih, mengorganisasi, dan mengartikan masukan informasi untuk menciptakan suatu gambarang tentang kehidupan (Saputra dan Samuel, 2013)

Menurut Duncan dalam Rusdan dkk (2014), persepsi dapat dirumuskan dengan pelbagai cara tetapi dalam ilmu perilaku khususnya psikologi, istilah ini dipergunakan untuk mengartikan perbuatan yang lebih dari sekedar mendengarkan, melihat, atau merasakan sesuatu. Perspsi yang signifikan itu ialah jika diperluas di luar jangkauan lima indra dan merupakan suatu unsur penting di dalam penyesuaian perilaku manusia. Untuk memahami persepsi adalah terletak pada pengenalan bahwa persepsi itu merupakan suatu penafsiran yang unik terhadap situasi, dan bukan suatu pencatatan yang benar terhadap situasi.

Rusdan dkk (2014) mendefinisikan beberapa hal yang berhubungan dengan Persepsi :

- Persepsi Sosial merupakan suatu keadaan yang berhubungan langsung dengan bagaimana seseorang individu melihat dan memahami orang lain

- Atribusi didefinisikan sebagai suatu proses bagaimana seseorang mencari kejelasan sebab-sebab dari perilaku orang lain

- Stereotype merupakan suatu proses dalam menilai seseorang atas dasar keyakinan individu tentang ciri-ciri atau sifat-sifat yang dimiliki oleh kelompok orang itu.

- Peranan sikap dalam kehidupan manusia memungkinkan pemilihan perilaku yang cukup mantap terhadap jenis obyek yang dihadapi. Sikap akan memberikan penilaian untuk menerima atau menolak obyek atau 
produk yang dihadapi. Sikap adalah keadaan jiwa atau mental serta pikiran yang dipersiapkan untuk memberikan tanggapan terhadap suatu obyek, baik positif maupun negatif. Dalam kegiatan pemasaran, pemasar berusaha agar produk yang dipasarkannya ditanggapi positif oleh konsumen.

- Sikap merupakan keadaan yang berlangsung lama dan bukan bersifat sementara. Sikap yang stabil dan konsisten membantu individu untuk mengorganisir proses mental dan perilaku mereka. Sikap positif terhadap produk yang dipasarkan bukan berarti konsumen telah membeli produk tersebut, melainkan sikap positif tersebut telah membantu pemasar mengetahui penerimaan konsumen terhadap produknya.

Menurut pendapat Robbin (2003) dalam Rusdan dkk (2014) bahwa sikap adalah pernyataan atau pertimbangan evaluatif, baik yang menguntungkan atau tidak menguntungkan, mengenai objek, orang atau peristiwa. Sedangkan Keitner (2001) dalam Rusdan dkk (2014) mengatakan bahwa sikap didefinisikan sebagai kecendrungan merespons sesuatu secara konsisten untuk mendukung atau tidak mendukung dengan memperhatikan suatu objek, orang atau situasi tertentu.

Seseorang dapat menunjukkan sikap atas suatu peristiwa setelah adanya akumulasi dari pengetahuan yang nantinya dapat membentuk suatu keyakinan dan pendapat; adanya perasaan dan emosional yang berpengaruh untuk bertindak; dan perilaku yang ditunjukkan dengan cara tertentu. Jadi ada tiga unsur utama yang terdapat dalam sikap yakni unsur kognitif, afektif dan perilaku. Sikap dapat dihubungkan dengan bentuk perilaku seseorang atas suatu peristiwa dapat menunjukkan perilaku positip dan atau perilaku negative (Rusdan dkk, 2014).

\section{Pengaruh Lingkungan Masyarakat terhadap Pemasaran}

Johnson (2002) menyatakan masyarakat adalah salah satu kekuatan lingkungan yang memaksa perusahaan pemasaran untuk mengikuti perubahan budaya dan nilai-nilai sosial, perilaku-perilaku, dan tradisi-tradisi yang membentuk peradaban sebuah masyarakat. Faktor-faktor ini mempengaruhi pemasaran dengan tiga cara penting. Pertama, trend sosial dan budaya menghasilkan pengenalan produk baru dan praktik pemasaran baru. Pada masa ini di Indonesia dan di seluruh dunia, tekanan waktu dan jarak dari orang tercinta menjadi isu penting bagi masyarakat. Untuk itu internet, laptop dan telepon seluler saat ini disediakan oleh perusahaan pemasaran sehingga orang dapat tetap berhubungan dengan orang tercintanya dan bahkan rekan kerjanya dimanapun ia berada. 
Kedua, produk baru dan aktivitasaktivitas pemasaran yang lain memiliki pengaruh pada tren sosial dan budaya. Produk hasil inovasi baru seperti sebuah kamera digital dan televisi satelit memiliki dampak yang besar pada hidup kita. Seperti bagaimana pentingnya telepon selular bagi remaja-remaja yang aktif dalam kehidupan sosial. Iklan dan tehnik-tehnik promosi yang lain juga turut mempengaruhi perilaku dan nilai-nilai yang ada dalam masyarakat kita (Johnson, 2002).

\section{Teori Budaya Konsumen}

Arnould dan Thompson (2005) menyatakan bahwa "Consumer Culture Theory is a marketing school of thought interested in studying consumption choices and behaviours from a social and cultural point of view, as opposed to an economical or psychological one. It does not offer a grand unifying theory but "refer to a family of theoretical perspectives that address the dynamic relationships between consumer actions, the marketplace, and cultural meanings".

Selanjutnya Arnould (2006) menambahkan bahwa "Consumer culture is viewed as "social arrangement in which the relations between lived culture and social resources, between meaningful ways of life and the symbolic and material resources on which they depend, are mediated through markets".
Dari kedua pengertian di atas dapat disimpulkan bahwa teori budaya konsumen adalah pemikiran para ahli pemasaran yang merupakan abstraksi dari kondisi empiris konsumen yang dilihat dari kondisi sosial dan budaya yang berhubungan dengan perilaku konsumen.

\section{METODE PENELITIAN}

Metode yang digunakan dalam penelitian ini adalah metode deskriptif dengan menggunakan pendekatan sampel survey pada sebagian populasi. Digunakannya metode penelitian ini dimaksudkan untuk memberikan gambaran yang komprehensif tentang persepsi dan sikap masyarakat Nusa Tenggara Barat terhadap rencana implementasi wisata halal di Nusa Tenggara Barat.

Data utama yang dibutuhkan dalam penelitian ini berupa data primer yang bersumber dari masyarakat Nusa Tenggara Barat. Selain itu, digunakan pula data skunder yang dalam penelitian ini merupakan data penunjang yang bersumber dari pelaku usaha kepariwisataan di Nusa Tenggara Barat, serta publikasi, laporan, dan dokumen lain yang mendukung.

Data dikumpulkan melalui wawancara dengan responden (masyarakat) dan pihak pelaku bisnis kepariwisataan dengan 
berpedoman pada daftar pertanyaan yang telah disusun. Sedangkan untuk data sekunder yang bersumber dari laporan dan publikasi lainnya, teknik pengumpulan data yang digunakan adalah dokumentasi.

Populasi dalam penelitian ini adalah seluruh masyarakat Nusa Tenggara Barat di Pulau Lombok. Berdasarkan pertimbangan luasnya wilayah, kesulitan medan secara geografis, dan banyaknya jumlah penduduk, maka teknik sampling yang digunakan adalah purposive sampling, dan fokus pada Kota Mataram, Senggigi di Lombok Barat, Malaka di Lombok Utara, Sukarara dan Kuta di Lombok Tengah, dengan pertimbangan konsentrasi kegiatan kepariwisataan yang lebih besar dan lebih banyak .

Komponen masyarakat yang akan dipilih sebagai responden bervariasi, yakni : aparat (desa, dusun, RT), tokoh pemuda, tokoh pendidikan, tokoh agama, dan tokoh masyarakat, serta pelaku bisnis ( Pemilik hotel, restoran, pedagang, trek organizer, porter, guider, dan lain-lain ). Jumlah responden dalam penelitian ini ditentukan secara purposive sampling dengan metode quota sampling sebanyak 100 orang dengan pertimbangan belum diketahui secara pasti jumlah populasi dari masing-masing kelompok sampel.
Variabel yang akan dianalisis meliputi

- Persepsi yakni pandangan masyarakat Nusa Tenggara Barat terhadap keberadaan rencana implementasi wisata syariah (wisata halal) di Nusa Tenggara Barat dan program pengembangan kepariwisataan di Nusa Tenggara Barat yang diutarakan dalam bentuk pandangan negatif hingga positif.

- Sikap yakni penilaian masyarakat Nusa Tenggara Barat terhadap keberadaan rencana implementasi wisata syariah (wisata halal) di Nusa Tenggara Barat dan program pengembangan kepariwisataan di Nusa Tenggara Barat, yang diutarakan dalam dalam bentuk suka-tidak suka atau setuju-tidak setuju.

Aspek-aspek yang diukur dalam persepsi dan sikap ini (dikutip dari Rusdan dkk (2014) yang meneliti tentang geopark Rinjani) meliputi:

- Keberadaan rencana implementasi wisata syariah (wisata halal) di Nusa Tenggara Barat Nusa Tenggara Barat

- Pengembangan rencana implementasi wisata syariah (wisata halal) di Nusa Tenggara Barat Nusa Tenggara Barat 
- Manfaat pengembangan wisata syariah (wisata halal) Nusa Tenggara Barat terhadap ekonomi kreatif.

- Manfaat pengembangan wisata syariah (wisata halal) Nusa Tenggara Barat terhadap pendapatan masyarakat.

- Manfaat pengembangan wisata syariah (wisata halal) Nusa Tenggara Barat terhadap pendapatan daerah ( sumber PAD )

- Dampak pengembangan wisata syariah (wisata halal) Nusa Tenggara Barat terhadap kelestarian lingkungan.

- Dampak pengembangan wisata syariah (wisata halal) Nusa Tenggara Barat terhadap pergeseran budaya.

- Kesesuaian keinginan masyarakat dengan kebijakan pengembangan wisata syariah (wisata halal).

- Keberlanjutan pengembangan wisata syariah (wisata halal) di wilayah Nusa Tenggara Barat.
- Aspek yang berkaitan dengan rencana implementasi wisata syariah (wisata halal) di Nusa Tenggara Barat.

Penelitian ini dianalisis dengan dengan Statistik deskriptif (descriptive statistics) yang juga disebut statistik deduktif (deductive statistics) merupakan analisis yang paling mendasar untuk menggambarkan keadaan data secara umum. Analisis statistik deskriptif ini meliputi frekuensi, deskriptif, eksplorasi data, tabulasi silang dan analisis rasio. Penyajian datanya akan dilakukan dalam bentuk tabel, grafik dan sebagainya. Penerapan statistic deskriptif dilakukan pada

Indeks Persepsi dan sikap Masyarakat yang diperoleh dengan matriks dari Rusdan dkk (2014) berikut ini Tabel 1 . Indeks Persepsi dan sikap Masyarakat

Tabel 1

Indeks Persepsi dan Sikap Masyarakat

\begin{tabular}{|l|l|l|l|l|l|l|l|}
\hline \multirow{2}{*}{ No Resp. } & \multicolumn{5}{c|}{ Aspek } & \multirow{2}{*}{ Total Skor } \\
\cline { 2 - 8 } & A & B & C & $\cdots$ & $\cdots$ & Z & \\
\hline 1 & & & & & & & \\
\hline 2 & & & & & & & \\
\hline$\cdots \cdots$ & & & & & & & \\
\hline$\ldots \ldots \ldots$ & & & & & & & \\
\hline $\mathrm{N}$ & & & & & & & \\
\hline
\end{tabular}




\begin{tabular}{|c|l|}
\hline Skor Keseluruhan & $\sum$ \\
\hline Indeks Persepsi dan sikap & $\sum / \mathrm{n}$ \\
\hline
\end{tabular}

Selanjutnya, kriteria nilai atas persepsi dan sikap sesuai dengan tabel berikut:

\section{Tabel 2}

\section{Kriteria Persepsi dan Sikap Masyarakat}

\begin{tabular}{|l|c|c|c|}
\hline No. & Angka Indeks & Sikap & Persepsi \\
\hline 1 & $1,00-1,80$ & Sangat negative & Sangat jelek \\
\hline 2 & $1,80 \leq 2,60$ & Negative & Jelek \\
\hline 3 & $2,60 \leq 3,40$ & Cukup positif & Bakup baik \\
\hline 4 & $3,40 \leq 4,20$ & Positif & Sangat Baik \\
\hline 5 & $4,20 \leq 5,00$ & Sangat positif & \\
\hline
\end{tabular}

Diagram Kartesius yang digunakan untuk menggambarkan hubungan persepsi dan sikap dengan memperhatikan nilai-nilai positif, netral, dan negatif, sebagaimana dijelaskan dalam tabel berikut.

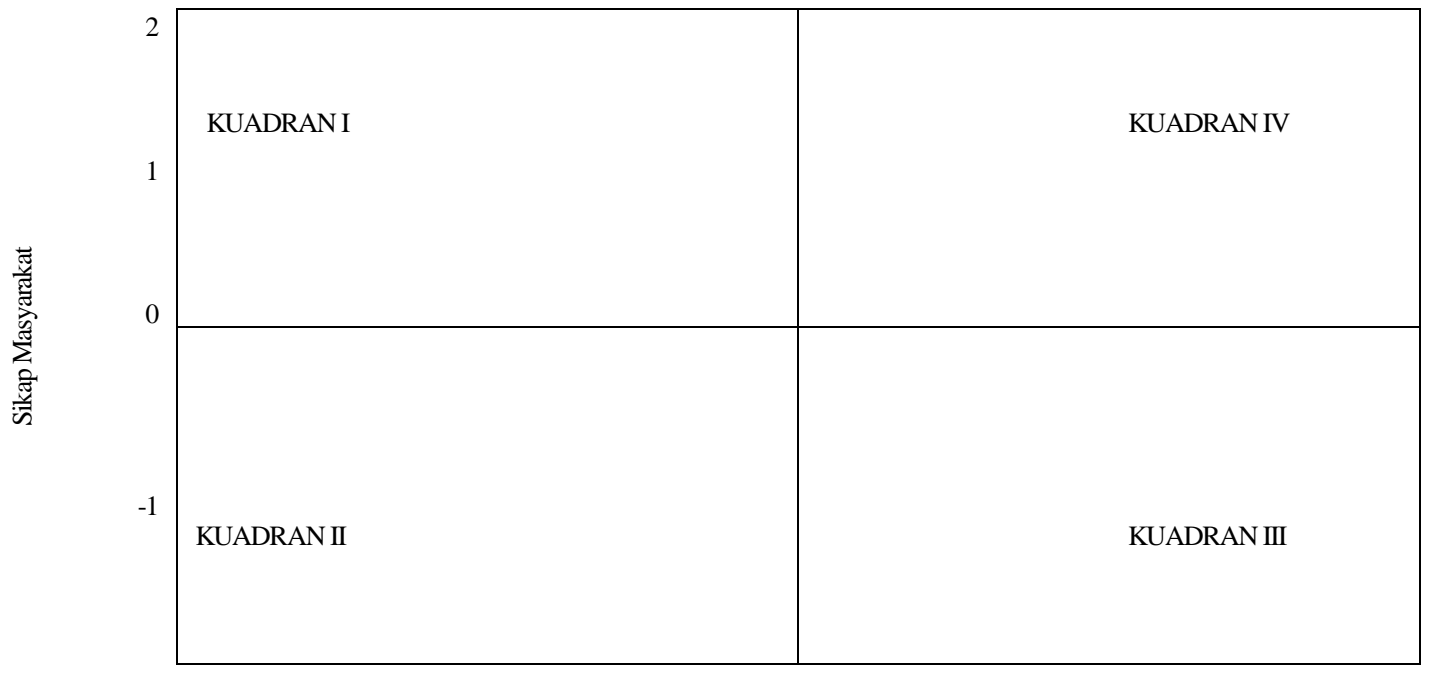

Online ISSN : 2540-8402 | Print ISSN : 2540-8399 
$-2$

Gambar 1. Diagram Kartesius Persepsi dan

Sikap Masyarakat terhadap

Rencana Penerapan Wisata

Syariah di Nusa Tenggara Barat

- Kuadran I menunjukkan aspek yang dipersepsikan rendah, namun disikapi tinggi, perlu kebijakan yang meningkatkan persepsi.

- Kuadran II menunjukkan aspek yang dipersepsikan dan disikapi rendah, perlu kebijakan yang meningkatkan persespsi dan sikap.

- Kuadran III menunjukkan aspek yang dipersepsikan tinggi, namun disikapi rendah, perlu kebijakan yang meningkatkan sikap.

- Kuadran IV menunjukkan aspek yang dipersepsikan dan disikapi tinggi, perlu
Persepsi Masyarakat

kebijakan yang mempertahankan sikap dan persepsi.

\section{PEMBAHASAN}

Berdasarkan hasil penelitian yang telah dilakukan terhadap 100 orang responden melalui kuesioner yang telah disebarkan, maka diperoleh data dari responden mengenai alamat, umur, pekerjaan ,pendapatan, dimana mendapat informasi tentang implementasi wisata syariah di NTB.

Untuk lebih jelasnya data mengenai karakteristik responden tersebut akan dijelaskan sebagai berikut:

Karakteristik responden berdasarkan usia sebagai berikut:

Tabel 3

Karakteristik Responden Berdasarkan Usia

\begin{tabular}{|c|c|c|c|}
\hline No & Usia & Jumlah Responden (orang) & Persentase(\%) \\
\hline 1 & $20-25$ & 29 & 29 \\
\hline 2 & $26-30$ & 31 & 31 \\
\hline 3 & $31-35$ & 21 & 21 \\
\hline 4 & $36-40$ & 7 & 7 \\
\hline
\end{tabular}




\begin{tabular}{|c|c|c|c|}
\hline 5 & $>41$ & 12 & 12 \\
\hline \multicolumn{2}{|c|}{ Total } & 100 & 100 \\
\hline
\end{tabular}

Berdasarkan tabel 3 di atas, dapat diketahui bahwa responden dalam penelitian ini di dominasi oleh umur 26 -
30 tahun dengan jumlah 31 orang dan persentase sebesar $31 \%$.

Tabel 4

Karakteristik Responden Berdasarkan Tempat Tinggal

\begin{tabular}{|c|l|c|c|}
\hline No & \multicolumn{1}{|c|}{ Tempat Tinggal } & $\begin{array}{c}\text { Jumlah Responden } \\
\text { (orang) }\end{array}$ & Persentase (\%) \\
\hline 1 & Lombok Utara & 20 & 20 \\
\hline 2 & Lombok Barat & 15 & 15 \\
\hline 3 & Lombok Tengah & 25 & 25 \\
\hline 4 & Lombok Timur & 20 & 20 \\
\hline 5 & Mataram & 20 & 20 \\
\hline & Total & 100 & 100 \\
\hline
\end{tabular}

Sumber: data Primer Diolah

Berdasarkan tabel 4. di atas dapat dilihat bahwa seperempat dari total responden adalah berasal dari Lombok Tengah yaitu sebanyak 25 orang atau sebesar 25 persen. Ini dikarenakan Lombok Tengah adalah salah satu kabupaten di Pulau
Lombok yang memiliki banyak tempat wisata, sedangkan responden yang paling sedikit adalah berasal dari Lombok Utara yaitu sebanyak 15 orang atau 15 persen.

Tabel 5

Karakteristik Responden Berdasarkan Pekerjaan

\begin{tabular}{|c|c|c|c|}
\hline No & Jenis Pekerjaan & $\begin{array}{c}\text { Jumlah } \\
\text { Responden } \\
\text { (orang) }\end{array}$ & $\begin{array}{c}\text { Persentase } \\
(\%)\end{array}$ \\
\hline
\end{tabular}




\begin{tabular}{|c|l|c|c|}
\hline 1 & Tokoh Pendidikan & 15 & 15 \\
\hline 2 & Tokoh pemuda & 10 & 10 \\
\hline 3 & $\begin{array}{l}\text { Pelaku bisnis ( Pemilik hotel, restoran, pedagang, } \\
\text { trek organizer, porter, guider, dan lain-lain ) }\end{array}$ & 40 & 40 \\
\hline 4 & Aparat (desa, dusun, RT) & 15 & 15 \\
\hline 5 & Tokoh Agama & 10 & 10 \\
\hline 6 & Tokoh Masyarakat Total & 10 & 10 \\
\hline \multicolumn{2}{r|}{$\quad 100$} & 100 \\
\hline
\end{tabular}

Sumber: Data Primer Diolah

Dari tabel 5 di atas dapat dilihat bahwa sebagian besar responden adalah masyarakat yang berprofesi sebagai Pelaku bisnis ( Pemilik hotel, restoran, pedagang, trek organizer, porter, guider, dan lain-lain ) yaitu sejumlah 40 orang atau $40 \%$.

\section{Tabel 6}

\section{Karakteristik Responden Berdasarkan Pendapatan}

\begin{tabular}{|c|l|c|c|}
\hline No & \multicolumn{1}{|c|}{ Pendapatan Per Bln } & Jumlah Responden (orang) & $\begin{array}{c}\text { Persentas } \\
\mathrm{e}(\%)\end{array}$ \\
\hline 1 & $<$ Rp. 3.000 .000 & 67 & 67 \\
\hline 2 & Rp. 3.000.000-5.000.000 & 23 & 23 \\
\hline 3 & Rp. 5.000.000-7.500.000 & 10 & 10 \\
\hline \multicolumn{2}{|c|}{ Total } & 100 & 100 \\
\hline
\end{tabular}

Sumber: Data Primer Diolah

Dari tabel 6 di atas dapat disimpulkan bahwa responden yang paling banyak adalah responden yang memiliki pendapatan perbulan paling banyak sebesar < Rp. 3.000 .000 sebanyak 67 orang atau sama dengan $67 \%$.

\section{Tabel 7}

Karakteristik Responden tentang implementasi wisata syariah di NTB

\begin{tabular}{|c|l|c|c|}
\hline No & Dimana Mendapat informasi tentang implementasi wisata \\
syariah di NTB & $\begin{array}{c}\text { Jumlah } \\
\text { Responden } \\
\text { (orang) }\end{array}$ & $\begin{array}{c}\text { Persentase } \\
(\%)\end{array}$ \\
\hline 1 & Koran Lokal & 57 & 57 \\
\hline
\end{tabular}




\begin{tabular}{|c|l|c|c|}
\hline 2 & Internet & 43 & 43 \\
\hline \multicolumn{2}{r|}{ Total } & 100 & 100 \\
\hline
\end{tabular}

Sumber: Data Primer Diolah

Dari tabel 7 di atas dapat disimpulkan bahwa responden yang mendapat informasi tentang implementasi wisata syariah di NTB yang paling banyak adalah responden yang mendapat informasi tentang implementasi wisata syariah di NTB di Koran Lokal sebanyak 57 orang sama dengan $57 \%$. sedangkan yang paling sedikit adalah yang mendapat informasi tentang implementasi wisata syariah di NTB di Internet sebanyak 43 orang dengan persentasi $43 \%$.

\section{Hasil Penelitian}

\section{Persepsi Masyarakat Terhadap Rencana}

Implementasi Wisata Halal di Nusa

\section{Tenggara Barat}

Setelah dilakukannya survei maka didapat sejumlah data mengenai persepsi masyarakat terhadap implementasi wisata halal di Nusa
Tenggara Barat seperti tercantum dalam tabel berikut ini.

Dalam tabel 3 tertera perhitungan indeks persepsi masyarakat terhadap rencana implementasi wisata halal di Nusa Tenggara Barat. Dari perhitungan didapatkan nilai indeks persepsi sebesar 3.41. Sesuai dengan tabel kriteria persepsi dan sikap masyarakat maka diketahui hasil ini berada di kisaran 3,40 $\leq 4,20$. Ini artinya masyarakat Nusa Tenggara Barat memiliki persepsi yang BAIK terhadap rencana penerapan wisata halal di daerah ini.

Setelah menganalisis persepsi masyarakat tentang rencana implementasi wisata halal di Nusa Tenggara Barat maka selanjutnya perlu dianalisis tentang sikap masyarakat terhadap hal yang sama. Dengan demikian diketahui apakah persepsi yang BAIK tersebut berlanjut pada sikap yang searah atau tidak.

Tabel 3

Persepsi Masyarakat Terhadap Implementasi Wisata Halal Di Nusa Tenggara Barat

\begin{tabular}{|c|c|c|c|c|c|c|c|c|c|c|}
\hline \multicolumn{10}{|c|}{ Persepsi Masyarakat } \\
\hline Aspek & C1 & C2 & C3 & C4 & C5 & C6 & C7 & C8 & C9 & Total \\
\hline Rata-rata & 3.36 & 2.19 & 3.63 & 3.75 & 3.89 & 3.6 & 3.26 & 3.13 & 3.94 & \\
\hline
\end{tabular}




\begin{tabular}{|c|c|c|}
\hline Skor Keseluruhan & $\sum$ & 341.3611 \\
\hline Indeks Persepsi & $\sum / \mathrm{n}$ & 3.413611 \\
\hline
\end{tabular}

Tabel 4

Sikap Masyarakat Terhadap implementasi wisata halal di Nusa Tenggara Barat

\begin{tabular}{|c|c|c|c|c|c|c|c|c|c|c|}
\hline & \multicolumn{7}{|c|}{ Sikap Masyarakat } & \\
\hline Aspek & D10 & D11 & D12 & D13 & D14 & D15 & D16 & D17 & D18 & Total \\
\hline $\begin{array}{c}\text { Rata- } \\
\text { rata }\end{array}$ & 3.71 & 3.96 & 3.9 & 3.54 & 3.83 & 3.66 & 3.11 & 3.27 & 3.83 & \\
\hline \multicolumn{8}{|c|}{ Skor Keseluruhan } & & $\sum$ & 364.3611 \\
\hline \multicolumn{8}{|c|}{ Indeks sikap } & $\sum / \mathrm{n}$ & 3.643611 \\
\hline
\end{tabular}

Dari tabel 4 di atas diketahui bahwa nilai indeks sikap masyarakat Nusa Tenggara Barat adalah 3.64. Untuk mengukur positif atau tidaknya nilai tersebut maka perlu dimasukkan ke dalam tabel kriteria sikap. Dari tabel kriteria sikap diketahui bahwa nilai 3.64 berada di kisaran $3,40 \leq 4,20$. Ini artinya nilai indeks sikap masyarakat NTB terhadap rencana implementasi wisata halal di daerahnya POSITIF.

Selanjutnya bila dibandingkan dengan indeks persepsi maka diketahui bahwa persepsi dan sikap masyarakat NTB terhadap rencana implementasi wisata halal di industry pariwisata NTB searah. Hal ini mengingat masyarakat mempersepsikan penerapan wisata halal sebagai hal yang BAIK.

\section{Hubungan Persepsi Dan Sikap}

\section{Masyarakat}

Untuk menggambil kebijakan terhadap tim peneliti menggunakan Diagram Kartesius yang mampu menggambarkan hubungan persepsi dan sikap dengan memperhatikan nilai-nilai positif, netral, dan negatif. Dalam tabel berikut adalah bentuk dari Diagram Kartesius yang menunjukkan pertemuan antara rata-rata dari nilai persepsi dan sikap masyarakat terhadap rencana implementasi wisata halal di NTB.

Dalam diagram Kartesius di atas terlihat ratarata persepsi masyarakat di sumbu $\mathrm{X}$ dan ratarata sikap masyarakat di sumbu $Y$. Persinggungan antara $\mathrm{X}$ dan $\mathrm{Y}$ dalam kasus Persepsi dan sikap Masyarakat terhadap Rencana Penerapan Wisata Syariah di Nusa 
Tenggara Barat ternyata terdapat di kuadran IV. Kuadran ini menunjukkan aspek yang dipersepsikan dan disikapi tinggi, perlu kebijakan yang mempertahankan sikap dan persepsi.

\section{Pembahasan}

Dari indeks persepsi dan sikap diketahui bahwa masyarakat Nusa Tenggara Barat baik masyarakat umum maupun masyarakat penggiat pariwisata memiliki visi yang sejalan dengan apa yang akan dijalankan oleh pemerintah provinsi NTB. Ini diketahui dari hasil penelitian yang menunjukkan bahwa persepsi dan sikap sejalan, dalam artian bahwa masyarakat NTB menganggap rencana tersebut BAIK dan bersikap POSITIF terhadap rencana tersebut. Dari saran-saran yang dijaring oleh tim peneliti diketahui bahwa masyarakat NTB ingin mempercepat dilaksanakannya wisata halal di daerahnya. Hal ini menunjukkan kesadaran masyarakat NTB akan dampak positif dari model pariwisata tersebut.

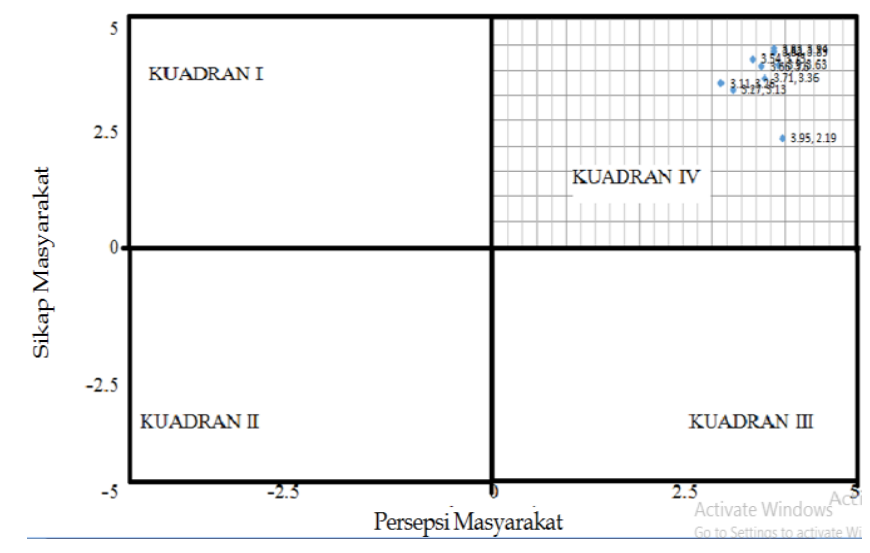

Gambar 2.

Diagram Kartesius Persepsi dan sikap Masyarakat terhadap Rencana Penerapan Wisata Syariah di Nusa Tenggara Barat

Dari analisis Diagram Kartesius diketahui bahwa hasil rencana penerapan wisata halal dipersepsikan dan disikapi sangat tinggi ini mengingat hubungan antara wisata halal tersebut dengan agama mayoritas yang dianut warga
NTB yaitu Islam. Untuk pengambil keputusan dalam hal ini Pemerintah NTB harus membuat kebijakan yang searah dengan hasil tersebut yaitu membuat kebijakan yang 
mempertahankan persepsi dan sikap itu tetap BAIK dan POSITIF.

\section{SIMPULAN}

Masyarakat Nusa Tenggara Barat memiliki persepsi yang BAIK terhadap rencana penerapan wisata halal di daerah ini. Masyarakat Nusa Tenggara Barat memiliki sikap yang POSITIF terhadap rencana penerapan wisata halal di daerah ini. Dari diagram Kartesius diketahui bahwa hasil rencana penerapan wisata halal dipersepsikan dan disikapi sangat tinggi oleh Masyarakat NTB

Untuk pengambil keputusan dalam hal ini Pemerintah NTB harus membuat kebijakan yang mempertahankan persepsi dan sikap itu tetap BAIK dan POSITIF. Dengan membuat kebijakan yang konkrit terkait dengan implementasi pariwisata halal, sehingga tidak sekedar pada tataran hukum atau peraturan daerah. Selain itu sosialisasi perlu dipercepat sehingga masyarakat paham bagaimana wisata halal tersebut akan diterapkan.

\section{DAFTAR PUSTAKA}

Anonim,

www.disbudpar.ntbprov.go.id, 2015

Anonim, (2015) Laporan Akhir Kajian pengembangan wisata Syariah
(2015)

http://gayahidup.republika.co.id/ 29 Maret 2016

Arnould, E. J. (2006) Consumer culture theory: retrospect and prospect, . European Advances in Consumer Research 7 (1): 605-607.

Arnould, E. J.; and Thompson, C. J. (2005), Consumer culture theory (CCT): Twenty Years of Research, Journal of Consumer Research 31 (4): 868-882

Johnson, E. M., (2002) Fundamentals of Marketing, Fourth Edition, American Management Association

Kementerian Pariwisata RI, (2015) Laporan Akhir Kajian pengembangan wisata Syariah

Kotler, P. dan Armstrong, G., (2008), Principles of Marketing, Prentice Hall Inc., Upper Saddle River, New Jersey.

Kotler, P. (2003), Marketing Management, 11th ed, New Jersey: Prentice Hall International Inc.

Kotler, P. dan Armstrong, G. (2001). Principle of marketing, 7th ed. New Jersey: Prentice Hall, Inc.

Kotler, P. (2000), Marketing Management, Millennium ed. New Jersey: Prentice Hall International Inc. 
Kusmaningrum dan Dian. (2009). PersepsiWisatawan Nusantara terhadap Daya Tarik di Kota Palembang. Yogyakarta: Universitas Gadjah Mada (Tesis).

Rusdan dkk (2014), Persepsi dan Sikap Masyarakat Lingkar Gunung Rinjani Terhadap Industri Pariwisata (Suatu Upaya Menyongsong Rinjani sebagai Geopark Dunia), Laporan Penelitian, Magister Manajemen, Univ. Mataram
Saputra, Rico dan Samuel Hatane. (2013). Analisis Pengaruh Motivasi, Persepsi Sikap Konsumen Terhadap Keputusan Pembelian Mobil Daihatsu Xenia di Sidoarjo. Jurnal Manajemen Pemasaran Vol. 1 No.1 hal. 1-12.

Schiffman, Leon. dan Kanuk, Leslie Lazar. (2008) Perilaku Konsumen (edisi ketujuh). PT. Indeks, Jakarta.

1) $\mathrm{e}$ 